\title{
THE EVALUATION OF IMPACT OF MUNICIPALITIES' FISCAL COMPETITIVENESS ON ECONOMIC GROWTH
}

\section{Dovilè Ruplienė, ${ }^{1}$ Lina Garšvienè, ${ }^{2}$ Dalia Rudytė, ${ }^{3}$ Solveiga Skunčikienė, Roberta Bajorūniené ${ }^{5}$}

\begin{abstract}
The competition between municipalities is problematic due to a common misconception that rivalry is impossible because documents regulating finances are the same across all local self-governments. In contrast, scientific research shows that the livability of one municipality can differ to another because of differences in their social-economic benefits. This distinction is not conditioned by geographic location or other special features of the municipality but rather by the amount of funds assigned and allocated to social and public welfare. This article aims to reveal the factors pertaining to the municipalities' fiscal competitiveness that affect economic growth within the state. This has relevance as a reallocation of a municipality's expenditure could provide new possibilities towards increasing future revenue of the municipality. For reaching the aim is examined by evaluating the effect of municipalities' fiscal competitiveness on Lithuania's economic growth using the volume and structure of expenditure in its municipalities. Results show that the major channels determining the fiscal competitiveness of a region are human resources, the business sector, and the institutional environment, and that these differ among municipalities.
\end{abstract}

JEL Classification Numbers: H75, H76, R50; DOI: http://dx.doi.org/10.12955/cbup.v5.958

Keywords: municipality, fiscal competitiveness, budget revenue, budget expenditure.

\section{Introduction}

The competition between municipalities is problematic due to a common attitude that such competition does not exist because municipalities have the same regulatory documents to manage finances at the local self-government level. Currently, scientists are interested in the issues of financial management of the local self-government, while the amount of research into evaluating the municipality's competitiveness is rather modest. The problem, which has initiated this research, is the need to ascertain the factors that affect the economic growth of Lithuania through fiscal municipalities' competitiveness. In this article, fiscal competitiveness of a region is defined as the ability of the region to allocate budget expenditure in such a way that develops the potential to collect more taxes for the municipality budget. The article aims to reveal the opportunities for a municipality to increase its budget revenue through greater focus on expenditure disbursement in local selfgovernment. The objective of this research is to examine the effect of budget expenditure of the region (municipality) as elements of fiscal competitiveness on economic growth.

\section{Literature Review}

\section{Fiscal Competitiveness and its Relation with Regional Competitiveness}

The scientific literature contains extensive discussion about the definition of 'competitiveness' with this concept interpreted and analyzed at employee, company, city, region, state, and sector levels. In addition, the notion of competitiveness in scientific literature has often been associated with international trade, high exchange rate, and labor productivity (Gardiner et al., 2004; Kitson, et al., 2004; Meilienė \& Snieška, 2010).

Competitiveness of regions is discussed in the scientific literature. However, there is no uniform opinion about the concept of 'regional competitiveness'. To date, the works evaluating regional competitiveness have overlooked fiscal competitiveness apart from including it in calculations of competitiveness indices. Indicators of tax collection and expenditure of the public sector have been included as the constituent parts (Avila, 2014). This means that in scientific research the analysis of revenue and expenditure of the public sector contribute to evaluations of regional competitiveness. In scientific literature (Matuzevičiūtè et al., 2015; Rudytė \& Skunčikienè, 2015), the factors that

\footnotetext{
${ }^{1}$ Department of Economics, Šiauliai University, Lithuania, drupliene@yahoo.com

${ }^{2}$ Department of Economics, Šiauliai University, Lithuania, lina.garsviene@gmail.com

${ }^{3}$ Department of Economics, Šiauliai University, Lithuania, daliarudyte@gmail.com

${ }^{4}$ Department of Economics, Šiauliai University, Lithuania, skusolveiga@gmail.com

5 Šiauliai University, Lithuania, bajoruniene.roberta@gmail.com
} 
predetermine competitiveness are given as follows: institutional environment, macroeconomic situation, labor market, infrastructure, financial market, education, commodity (services) market, business, social environment, scientific infrastructure, and technology advances. Hence, numerous factors predetermine competitiveness, and moreover, they are closely related.

Despite no direct analysis of fiscal competitiveness and its impact on economic growth, several studies evaluate such when assessing the economic effects of fiscal decentralization (Kim, 2013; Baskaran \& Feld, 2013; Amagoh \& Amin, 2012). In addition, the scientific works examining the economic effects of fiscal policy measures evaluate fiscal competitiveness indirectly (Cottarelli \& Jaramillo, 2012; Boskin, 2012). When taking into account the collection of the municipality's budget revenue, fiscal competitiveness of a municipality becomes its exceptional appeal and ability to compete with other municipalities and ensure favorable conditions for business, create workplaces, and, at the same time, successfully collect budget revenue. According to the authors of this article, such a definition of fiscal competitiveness raises debate with budget expenditure depending on budget revenue.

The Channels of Impact of Regional Fiscal Competitiveness on Economic Growth

The scientific research that has evaluated factors determining the economic growth of regions has concentrated predominantly on the following aspects: the effect of human resources, the business sector, and institutional environment.

Fiscal competitiveness of a region depends on the amount of freedom the region has in determining their tax rate, applying for tax relief, or establishing procedures for allocating social benefits. There are many articles reporting the effect of fiscal decentralization on economic growth (Baskaran \& Feld, 2013; Kim, 2013; Boskin, 2012; Amagoh \& Amin, 2012; Thornton, 2007), although the research results have been disputed on occasions (Hammond \& Tosun, 2009).

Human resources are connected with the fiscal competitiveness of the region regarding both budget revenue and expenditure aspects. The greater the amount of human resources in the region, the greater the number of products produced by business and, therefore the higher amount of revenue for the budget. In scientific research, the effect of human resources on regional competitiveness and economic growth has been assessed using various indicators for human resources. Some research (Faggian et al., 2016; Gennaioli et al., 2011; Unger et al., 2011) is of a general nature where the factor of human resources has been assessed together with others determining competitiveness and economic growth. Several other studies have assessed the impact of human resources and institutional environment regarding the possibilities of state institutions having an effect on economic growth (Acemoglu, Gallego \& Robinson, 2014; Dias \& Tebaldi, 2012).

Education and the quality of the education system often serve as indicators in evaluating the impact of human resources on regional competitiveness and economic growth (Hanushek, 2013; CastelloCliment \& Hidalgo-Cabrillana, 2012). Others researchers assessing the impact of human resources on economic growth (e.g., O'Connor 2013; Audretsch \& Pena-Legazkue 2012) evaluate human resources by considering entrepreneurship under the assumption that initiative market participants are creative and contribute to the establishment of new companies.

The effect of the business sector on regional competitiveness is extensive and includes various factors: the structure of economics, foreign and local investments, entrepreneurship, and the number and size of companies, etc. These factors also affect the fiscal competitiveness of the region because they predetermine budget revenue and expenditure. In scientific literature, most attention is paid to evaluating the effect of foreign direct investments (FDI) on regional competitiveness and economic growth.

\section{Methodology}

The scientific methods employed in this research included analysis of scientific literature and legislation and a multiple regression analysis.

Considering fiscal competitiveness lacked a clear definition, for the purposes of this study in assessing regional competitiveness, fiscal competitiveness of the region was defined as the ability of that region to allocate budget expenditure in such a way that the people, economic entities, and all spheres of activity contribute more taxes to the budget of the municipality. 
An assumption of the study was that the ability of the municipality to collect additional revenue for the budget was directly connected with its economic growth.

The study period was 2005 to 2014 . This timeframe was chosen to provide enough observations for a statistically sound conclusion. Also, it partly eliminated the influence of cyclic economic recurrence that included periods of Lithuania entering the European Union resulting in rapid economic growth, the economic recession since 2008, and the current economic growth phase. In addition, this duration matched that typically used in research evaluating municipalities (regions), i.e., 10-20 years (Gennaioli, et al., 2011; Gardiner et al., 2004). The data from 60 municipalities of Lithuania were used.

The municipalities of one country are often chosen in similar types of research as in choosing several countries, or their groups, introduces the possibility of confounding differences relating to the regulation of municipalities (Jenčova et al., 2013). A limitation of the study was that the territory of Lithuania is small with municipalities close enough that business conditions of one municipality could affect the business sector of another. An overall assumption of the study was that the municipalities were comparable for purposes of the study. All municipalities were evaluated using the same methods. Data from 60 municipalities provided several variables for comparison and enabled a complex evaluation of the impact of factors determining economic growth.

This study used a two-stage model to achieve the research aim and determine how expenditure of municipalities influenced their economic growth. The variables in the model were calculated using the data of the Lithuanian Department of Statistics and Ministry of the Economy of the Republic of Lithuania (Lithuanian statistical system, 2017).

A primary econometric model was used to determine the general control factors, specific factors of budget expenditure influencing economic growth, and trends associated with the economic growth. Other factors expressed by the control variables in the model were also assessed. Three main factors were distinguished from the model: human resources, the business sector, and the institutional environment were each assigned two indicators.

The two indicators for 'human resources' were 'labor force content' (i.e., labor force per 1000 people) and 'cost' (i.e., average municipality wage) in the municipality. The study used the metric of labor force per 1000 in contrast to the level of labor force because the former reflected the number of people in general, rather than the working-age population. It was deemed more appropriate for revealing the municipality's potential productivity given the situation where a municipality's economic activity is high, but there may be many economically inactive groups (children and retired people). Children may be considered as the future labor force, but in the meantime, require municipality expenditure in maintenance of educational institutions. Retired citizens are not participants of the paid workforce and thus, do not contribute to such productivity. Therefore, it was assumed that the labor force content per 1000 people best reflected the municipality's productivity.

The two indicators for 'the business sector' were the 'number of companies' and the 'annual FDI per 1000 people'. The FDI indicator was used because it related to raising capital from external sources and providing greater opportunities for productivity and economic growth. In separate specifications of the model, the total number of companies, the number of small- and medium-sized enterprises, and the number of medium- and large-sized companies were evaluated. These latter additions were chosen because small- and medium-sized businesses are often perceived as the main business entities that promote economic activities and growth (Opafunso \& Adepoju, 2014; Smeaton et al., 2011; Grigencaitè \& Ivanovienè, 2010; Nwoye, 2010).

The two indicators for 'the institutional environment' in the model were 'state subsidies per 1000 people' and a 'dummy variable' denoting the existence or not of special status zones in the municipality, i.e., Industry Parks (IP) or Free Economic Zones (FEZ).

Each statistical indicator in the econometric model was treated as a separate variable, and the conclusions were drawn taking into account the statistical significance of the variables and the value of their coefficients (positive and negative).

Panel data was used in the research to deal with the different periods of time and different entities. In this way, it was possible to evaluate the impact of analyzed factors on municipalities' economic growth for the full period under analysis and in all municipalities of Lithuania. Therefore, the results 
of the regression analysis showed the overall results of all Lithuanian municipalities. A regression analysis was carried out using the method of least squares, and coefficients were calculated using robust heteroscedasticity-consistent standard errors. In the model, the differentiation of data was used to evaluate annual change in all variables, and logarithms were used to transform all analyzed dependencies into linear models.

The data analysis was done using GRETL econometric package. Multiple regression models were formed with gross domestic product (GDP) growth rate as a dependent variable. The expenditure indicator, calculated per 1000 people, removed the confounding effect of municipality size. The econometric model involved the following equation:

$$
\begin{aligned}
\Delta \ln \left(\operatorname{gdp}_{\mathrm{i}, \mathrm{t}}\right) & =\alpha+\mathrm{td}_{3} 2007+\ldots+\mathrm{td}_{20} 2014+\beta_{1} \Delta \ln \left(\exp _{\mathrm{i}, \mathrm{t}}\right)+\beta_{2} \Delta \ln \left(\exp _{\mathrm{i}, \mathrm{t}}\right) \cdot \mathrm{dens}+\beta_{3} \Delta \ln \left(\operatorname{lab}_{-} \text {force }_{\mathrm{i}, \mathrm{t}}\right)+ \\
& +\beta_{4} \Delta \ln \left(\text { wage }_{\mathrm{i}, \mathrm{t}}\right)+\beta_{5} \Delta \ln \left(\mathrm{ent}_{\mathrm{t}}\right)+\beta_{6} \Delta \ln \left(\mathrm{fdi}_{\mathrm{i}, \mathrm{t}}\right)+\beta_{7} \Delta \ln \left(\mathrm{sub}_{\mathrm{i}, \mathrm{t}}\right)+\beta_{8}\left(\mathrm{ip} \_ \text {fez }\right)+\beta_{9}\left(\mathrm{gdp}_{\mathrm{i}, \mathrm{t}-1}\right)+\mathrm{u}_{\mathrm{i}, \mathrm{t}}
\end{aligned}
$$

Where:

$\operatorname{gdp}_{\mathrm{i}, \mathrm{t}}=$ GDP per 1000 people in a municipality $\mathrm{i}$ in period $\mathrm{t}$;

$\alpha=$ a constant;

$\mathrm{td}_{\mathrm{t}}=$ time dummies;

$\beta=$ coefficients that reveal the impact of an independent factor on a dependent variable;

$\exp _{\mathrm{i}, \mathrm{t}}=\mathrm{a}$ municipality's expenditure per 1000 people in a municipality $\mathrm{i}$ in period $\mathrm{t}$;

lab_force $\mathrm{i}_{\mathrm{i}, \mathrm{t}}=$ labour force content per 1000 people in a municipality $\mathrm{i}$ in period $\mathrm{t}$;

wage $_{\mathrm{i}, \mathrm{t}}=$ average monthly wage per 1000 people in a municipality $\mathrm{i}$ in period $\mathrm{t}$;

ent $_{t}=$ the number of companies per 1000 people in a municipality $\mathrm{i}$ in period $\mathrm{t}$;

$\mathrm{fdi}_{i, \mathrm{t}}=$ annual FDI flow per 1000 people in a municipality $\mathrm{i}$ in period $\mathrm{t}$;

$\operatorname{sub}_{\mathrm{i}, \mathrm{t}}=$ state subsidies per 1000 people in a municipality $\mathrm{i}$ in period $\mathrm{t}$;

ip_fe $z_{i, t}=$ the existence or not of an industry park or special economic zone in a municipality $\mathrm{i}$ in period $\mathrm{t}$;

$\operatorname{gdp}_{\mathrm{i}, \mathrm{t}-1}=$ gross domestic product per 1000 people in a municipality $\mathrm{i}$ in period $\mathrm{t}-1$; and

$u i_{, t}=$ error of the model.

In different modifications of the model (Modification 1, Modification 2, Modification 3), ent ${ }_{t}$ revealed the total number of companies (ent_total) or the number of small- and medium-sized companies (ent_sm), or the number of medium- and large-sized companies (ent_mb).

Municipalities were distinguished by clusters according to population density (dens), and the interrelation between municipalities' expenditure and population density was included in the model (exp*dens). Municipalities whose population density exceeded 77.3 persons per $\mathrm{km}^{2}$ were ascribed to Cluster I, whereas municipalities with a lower population density were ascribed to Cluster II.

\section{Results and Discussion}

The results of the regression analyses evaluating the effect of the total expenditure of municipalities on economic growth are shown in Table 1. The main variable of the model for assessing the impact on municipalities' economic growth was municipalities' expenditure. This factor had a statistically significant effect on municipalities' economic growth ( $99 \%$ of probability), as well as on municipalities' expenditure per 1000 people. When increased by $1 \%$, the gross product of municipalities increased to about $0.80 \%$ on average. The interrelation between municipalities' expenditure and the population density influenced economic growth was statistically relevant. The inclusion of this interrelation variable into the model aimed to prove whether the impact of municipalities' expenditure per 1000 people would be greater in municipalities with higher population density. The research findings failed to substantiate the assumption of a higher population density higher and higher expenditure per 1000 people corresponding to a higher level of absolute expenditure, and, thus, a larger concentration of expenditure for the territory experiencing such. 
The model included two indicators for each of these three factors: human resources, the business sector, and institutional environment. Four of these indicators displayed a statistically meaningful result (Table 1). The human resources indicator of 'average monthly wage per 1000 people', the business sector indicators of 'number of companies' and 'annual FDI per 1000 people', and the institutional environment factor of 'state subsidies per 1000 people' showed a significant relationship with the municipalities' economic growth. All were positively related to economic growth, except budget subsidies, which had a negative result (Table 1). In respect to the condition of the business sector, the added variable of the number of small- and medium-sized companies also showed a significant and positive relationship with the municipality's economic growth.

The impact of the average monthly wage indicator for human resources can be explained by the growing wage increases that not only reflect the cost of labor (which is often thought to slow economic growth) but also the surge in purchasing power that occurs with increase in wages. The services sector is highly receptive to the increased earnings of the community. In addition, this factor is critical in presenting the municipality as an economically successful territory. In this respect, the territory can attract FDI, decrease emigration, and promote the establishment of small- and mediumsized companies within its territory.

Table 1: Results of multiple regressions on data of 60 Lithuanian municipalities and factors of human resources, the business sector, and the institutional environment

\begin{tabular}{|c|c|c|c|}
\hline \multirow{2}{*}{ Model Variables } & \multicolumn{3}{|c|}{ Coefficients calculated using robust heteroscedasticity-consistent errors } \\
\hline & Modification 1 & Modification 2 & Modification 3 \\
\hline Const & 0.0139 & 0.0135 & 0.0221 \\
\hline ld_exp & $0.7950 * * *$ & $0.7968 * * *$ & $0.7489 * * *$ \\
\hline ld_exp*dens & 0.0256 & 0.0235 & 0.0559 \\
\hline Id_lab_force & 0.4860 & 0.4852 & 0.5004 \\
\hline ld_wage & $0.6746 * * *$ & $0.6741 * * *$ & $0.7110^{* * *}$ \\
\hline ld_ent_total & $0.2949 *$ & & \\
\hline ld_ent_sm & & $0.3060 * *$ & \\
\hline ld_ent_mb & & & 0.0169 \\
\hline ld_fdi & $0.0598 * * *$ & $0.0598 * * *$ & $0.0585 * * *$ \\
\hline ld_sub & $-0.5473 * * *$ & $-0.5469 * * *$ & $-0.5467 * * *$ \\
\hline IP_FEZ & 0.0433 & 0.0429 & 0.0474 \\
\hline Id_GDP_1 & $-0.4106^{* * *}$ & $-0.4103 * * *$ & $-0.4105^{* * *}$ \\
\hline Adjusted R ${ }^{2}$ & 0.2639 & 0.2641 & 0.2607 \\
\hline $\begin{array}{l}\text { *** } 99.0 \% ; * * 95.0 \% \\
\text { id_exp = a municipali } \\
\text { id_exp*dens = interre } \\
\text { id_lab_force = labour } \\
\text { id_wage = average mo } \\
\text { id_ent = the number o } \\
\text { id_ent_sm = the numb } \\
\text { id_ent_mb = the numl } \\
\text { id_fdi = annual foreig } \\
\text { id_sub = state subsidi } \\
\text { ip_FEZ = existence o } \\
\text { environment) } \\
\text { id_GDP_1 }\end{array}$ & $\begin{array}{l}\text { \% significance levels }(\mathrm{n}= \\
\text { diture per } 1000 \text { people in } \\
\text { ween municipalities' exper } \\
\text { tent per } 1000 \text { people in a } \\
\text { ge per } 1000 \text { people in a m } \\
\text { ies per } 1000 \text { people in a m } \\
\text { ll- and medium-sized com } \\
\text { lium- and large-large com } \\
\text { vestments per } 1000 \text { peopl } \\
0 \text { people in a municipality } \\
\text { n industry park or special } \\
\text { oduct per } 1000 \text { people in a }\end{array}$ & $\begin{array}{l}\text { dlation density inclu } \\
\text { dicator of human res } \\
\text { cator of human reso } \\
\text { icator of business se } \\
\text { ariable of business s } \\
\text { ariable of business s } \\
\text { ity (indicator of bus } \\
\text { stitutional environm } \\
\text { in a municipality (i } \\
\text { period } t-1\end{array}$ & $\begin{array}{l}\text { n the model } \\
\text { es) } \\
\text { sector) } \\
\text { tor of institutional }\end{array}$ \\
\hline
\end{tabular}

Despite there being much variation considered about the effect of small- and medium-sized companies on economic growth, the results of this research show that such enterprises had a significant effect on the economic growth in Lithuania's municipalities during the period under analysis. Meanwhile, the evaluation of the effect of the number of medium- and large-sized companies on economic growth was based on the assumption these businesses operate more efficiently, achieve economies of scale, and be 
more competitive in local and international markets than the smaller ones. However, their impact on economic growth of Lithuania's municipalities was not evident.

While analyzing the influence of the FDI in this study, it was noticed that, on the one hand, FDI had a direct impact, whereas, on the other hand, it has a contrary relation with economic growth of the state. Kuliavienė \& Solnyškinienė (2014), Moraru (2013), Sandalcilar \& Altiner (2012), Ruplienė \& Garšvienè (2008) observed that the impact of FDI on advances in technology in the state depended greatly on the state's economic regulation (particularly concerning the regulation of labor and financial markets). A divergent relationship between FDI and economic growth was analyzed by Antwi, Atta Mills, Atta Mills \& Zhao (2013). The authors highlighted that a negative impact of FDI surfaces in cases where local producers lose their position in the market, where companies in a particular sector increase, and where the capital earned from investments outflows from the state in which the investments have been made. As well, the impact of FDI on economic growth depends on the state's institutions.

Study results for the business sector indicator of 'annual FDI flow per 1000 people' were encouraging, although the actual impact would be rather small. When FDIs increase by $1 \%$, the municipality's productivity grows by an average $0.06 \%$. On the one hand, the impact of FDI may be less apparent. However, on the other hand, there has been no research to support such notion.

The factor of the institutional environment was described by two indicators in the model: 'state subsidies per 1000 people' and a 'dummy variable' denoting the existence or not of special status territories (IP and FEZ). This study found the state subsidies flowing into the municipalities' budget as supplementary revenues inversely related to the economic growth of a municipality. When a municipality receives relatively large sums in the form of subsidies, it possible fails to seek other ways of creating productivity to collect tax revenue since the subsidies fill the shortage of funds. A statistically meaningful effect on the municipality's economic growth regarding whether IP or FEZ exist was not evident in this study.

Overall, the results of the model examining the effects of municipalities' total expenditure and control on economic growth, show that the municipalities' expenditure, the amount of an average wage, and the number of companies are indicators relating to economic growth, whereas the state subsidies, in contrast, appear to limit such growth.

\section{Conclusion}

Findings in scientific literature concur that the factors determining competitiveness are interrelated. Thus, an effect on one factor signals potential change in others. Fiscal competitiveness of a region may be defined as the ability of that region to allocate budget expenditure in such a way that people, economic entities, and all spheres of activity contribute more taxes to the budget of the municipality. The major channels determining the effect of regional fiscal competitiveness on economic growth in allocating expenditure for municipality programs are human resources, the business sector, and the institutional environment. In conducting this study and taking into account the amount and structure of expenditure in Lithuania's municipalities, summations were made with reference to the statistical significance of variables and the value of coefficients. The impact of the municipality's expenditure had no connection with the population density. The average wage in a municipality, the number of companies (size of no consequence), and the annual FDI were found to be indicators positively relating to economic growth. In contrast, an indicator negatively relating to economic growth was state subsidies to the municipality budgets. Thus, the research results show that the institutional environment can affect economic growth, though negatively in this case. As well, based on results with the average wage indicator, the greater the amount of human resources in the municipality the greater the productivity of business, and thus, more revenue for the budget. The amount and structure of human resources, when considering its value in education, entrepreneurship, and creativity of the community, provides for economic growth and collection of revenue for the municipality's budget over a longer period. The business sector affects the fiscal competitiveness of a municipality quite broadly as it includes a great number of imperative channels, such as the structure of economics, foreign and local investments, entrepreneurship, and the number and size of companies. All affect the fiscal competitiveness of a municipality because they affect budget revenue and expenditure. 


\section{Acknowledgement}

This scientific article is funded by the Research Council of Lithuania according to the project "The evaluation of municipalities' fiscal competitiveness in the context of economic growth" (2015-2018), registration No. MIP-013/2015.

\section{References}

Acemoglu, D., Gallego, F. A., \& Robinson, J.A. (2014). Institutions, human capital and development. Annual Review of Economics, 6(1), 875-912.

Amagoh, F., \& Amin, A. A. (2012). An Examination of the Impacts of Fiscal Decentralization on Economic. International Journal of Business Administration, 3(6), 72-81.

Antwi, S., Atta Mills, E. F. E., Atta Mills, G., \& Zhao, X. (2013). Impact of Foreign Direct Investment on Economic Growth: Empirical Evidence from Ghana. International Journal of Academic Research in Accounting, Finance and Management Sciences, 3(1), 18-25.

Audretsch, D. B., Hulsbeck, M., \& Lehmann, E. E. (2012). Regional competitiveness, university spillovers, and entrepreneurial activity. Small Business Economics, 39(3), 587-601.

Audretsch, D. B., \& Pena-Legazkue, I. (2012). Entrepreneurial activity and regional competitiveness: an introduction to the special issue. Small Business Economics, 39(3), 531-537.

Avila, J. (2014). 2014 Cities and Municipalities Competitiveness Index: Manual of Operations. Investment Enabling Environment (INVEST) Project. USAID. Retrieved March 1, 2017, from http://pdf.usaid.gov/pdf_docs/PA00K5T2.pdf

Baskaran, T., \& Feld, L. P. (2009). Fiscal Decentralization and Economic Growth in OECD Countries: Is there a Relationship? Cesifo Working Paper, 2721. Retrieved March 1, 2017, from

https://www.econstor.eu/bitstream/10419/30426/1/607953381.pdf

Boskin, M. J. (2012). Fiscal Policy for Economic Growth. The Economists' Voice, 9(2), 1-13.

Castello-Climent, A., \& Hidalgo-Cabrillana, A. (2012). The role of educational quality and quantity in the process of economic development. Economics of Education Review, 31, 391-409.

Cottarelli, C., \& Jaramillo, L. (2012). Walking Hand in Hand: Fiscal Policy and Growth in Advanced Economies. IMF Working Paper. Retrieved March 1, 2017, from https://www.imf.org/external/pubs/ft/wp/2012/wp12137.pdf

Dias, J., \& Tebaldi, E. (2012). Institutions, human capital, and growth: The institutional mechanism. Structural Change and Economic Dynamics, 23, 300-312.

Faggian, A., Partridge, M., \& Malecki, E. (2016). Creating an environment for economic growth: creativity, entrepreneurship or human capital? Retrieved March 1, 2017, from https://mpra.ub.uni-muenchen.de/71445/1/MPRA_paper_71445.pdf

Gardiner, B., Martin, R., \& Tyler, P. (2004). Competitiveness, Productivity and Economic Growth across the European Regions. Retrieved March 1, 2017, from

www.camecon.com/economic_intelligence_services/eu_regional/downloadable_files

Gennaioli, N., La Porta, R., Lopez-de-Silanes, F., \& Shleifer, A. (2011). Human capital and regional development. Retrieved March 1, 2017, from http://scholar.harvard.edu/files/shleifer/files/human_capital_qje_final.pdf

Grigencaitè, K., \& Ivanovienè, I. (2010). Smulkaus ir vidutinio verslo ekonominès situacijos analizè ir reikšmè šalies ekonomikai, jo skatinimas Šiaulių mieste [Small and Medium Enterprise (SME) Economic Situation Analysis and Importance for the National Economy, Its Support in Siauliai]. Retrieved February 20, 2017, from http://etalpykla.lituanistikadb.lt/fedora/objects/LT-LDB0001:J.04 2010 1367173547653/datastreams/DS.002.0.01.ARTIC/content

Hammond, G. W., \& Tosun, M. S. (2009). The Impact of Local Decentralization on Economic Growth: Evidence from U.S. Counties. Discussion Paper No. 4574. Retrieved March 1, 2017, from http://repec.iza.org/dp4574.pdf

Hanushek, E. A. (2013). Economic growth in developing countries: The role of human capital. Economics of Education Review, 37, 204-212.

Jenčova S., Litavcova E., Štefko R., \& Matovčíkova D. (2013). The impact of the economic crises on financing of municipalities in Slovakia. Polish journal of management studies, vol. 7, 167-178. Retrieved March 1, 2017, from https:// http://oaji.net/articles/2014/1384-1415188721.pdf

Kim, H. (2013). Fiscal decentralization and economic growth in Korea. Korea: Institute of Public Finance.

Kitson, M., Martin, R., \& Tyler, P. (2004). Regional competitiveness: an elusive yet key concept. Regional studies, 38.9, 991-999. Retrieved March 1, 2017, from https://michaelkitson.files.wordpress.com/2013/02/kitson-marrtin-tyler-rs-2004.pdf

Kuliavienè, A., \& Solnyškinienè, J. (2014). The Evaluation of the Impact of Foreign Direct Investment on Lithuanian Economy Using LAG-Analysis. Economics and Management, 19(1), 16-24.

Lithuanian statistical system (2017). Official Statistics Portal. Retrieved from http://www.stat.gov.lt/en/;jsessionid=3DB2CC22F135DE84AFF6F4C473788ECB

Matuzevičiūtė, K., Vaitekūnaitė, A., \& Butkus, M. (2015). Europos Sajungos šalių konkurencingumo ir jị lemiančių veiksnių vertinimas [Assessment of National Competitiveness of European Union Countries and Determining Factors]. Retrieved February 20, 2017, from http://www.su.lt/images/leidiniai/EVAP/2015_37/03_Matuzeviciute.pdf 
Meilienė, E., \& Snieška, V. (2010). Lietuvos pramonės konkurencingumo veiksniai eksporto politikos nuostatuose [Factors of Lithuanian Industrial Competitiveness in Export Policy Provisions]. Retrieved March 1, 2017, from https://www.mruni.eu/upload/iblock/f82/9_e.meiliene\%20ir\%20kt.pdf

Moraru, C. (2013). Foreign direct investment and economic growth in Romania. Theoretical and Applied Economics, 20(5), 125-134.

Nwoye, M. (2010). Entrepreneurship Development and Investment Opportunities in Nigeria. Lagos: Highcliff Publishers, Inc. Lagos.

O'Connor, A. (2013). A conceptual framework for entrepreneurship education policy: Meeting government and economic purposes. Journal of Business Venturing, 28, 546-563.

Opafunso, Z. O., \& Adepoju, O. O. (2014). The Impact of Small and Medium Scale Enterprises on Economic Development of Ekiti State, Nigeria. Journal of Economics and Sustainable Development, 5(16), 115-122.

Rudyte, D., Skunčikienè, S. (2015). Baltijos šalių konkurencingumą lemiančių veiksnių analizė [The Analysis of Determinants of Competitiveness in Baltic States]. Retrieved March 1, 2017, from http://www.lea2015.ef.vu.lt/wpcontent/uploads/2016/03/LEA2015-straipsniu-rinkinys-1_rev.pdf

Ruplienė, D., \& Garšvienė, L. (2008). Tiesioginių užsienio investicijų ịtaka šalies ekonominiam augimui [Impact of Foreign Direct Investment on Countries’ Economical Growth], Retrieved March 1, 2017, from http://etalpykla.lituanistikadb.lt/fedora/objects/LT-LDB0001:J.04 2008 1367161896483/datastreams/DS.002.0.01.ARTIC/content

Sandalcilar, A. R., \& Altiner, A. (2012). Foreign Direct Investment and Gross Domestic Product: An Application on ECO Region (1995-2011). International Journal of Business and Social Science, 3(22), 189-198.

Shane, S. (2009). Why encouraging more people to become entrepreneurs is bad public policy. Small Business Economics, 33(2), 141-149.

Smeaton, D., Hudson, M., Deraniyagala, S., Francavilla, F., Ng, M., Phillips, J., \& Salis, S. (2011). Impact of BIG Funding of Community Enterprise Overseas. Retrieved March 1, 2017, from http://www.biglotteryfund.org.uk/er_eval_community_enterprise_overseas_report.pdf

Thornton, J. (2007). Fiscal Decentralization and Economic Growth Reconsidered. Journal of Urban Economics, 61, 64-70.

Unger, J. M., Rauch, A., Frese, M., \& Rosenbusch, N. (2011). Human capital and entrepreneurial success: A meta-analytical review. Journal of Business Venturing, 26, 341-358. 